\title{
An Experimental Technique and Chemical Datasets analysis for Packed Food
}

\author{
Prof. Muhamad Angriawan \\ IRC Russia \\ muhamadaggriawan@mail.ru
}

Abstract:

The assurance of rotator for the specific kind of suspension needs some crucial data. The particles, which are accessible in different sizes, their assignment in the medium, one of a kind thickness, thickness, etc are the essential principles. It comprises of a basic screw type transport which evacuates the stored solids. The speed keeps up could be around $8000 \mathrm{rpm}$ in the extent of 70-75\% mud dampness. In this paper we are talking about centrifugation of stick juice in the sugar business.

Keywords: Packed Items, Centrifugation, consumptionsetc.

\section{INTRODUCTION}

Centrifugation is one of the principal unit tasks in the sugar business. The detachment of suspended particles and natural salts at an essential stage and at an encompassing temperature (at the virus stage) advantageously affects explanation. Something else, at a higher temperature the disintegration of suspended particles is bound to occur. In the last case, the detachment will be progressively troublesome and will build the scale statement in a warmth exchanger just as increment the consistency. This decrease of mud will likewise diminish the volume of mud typically acquired from the clarifier, which is around $25 \%$ on stick. Thusly, the heap on the vacuum revolving channel will be diminished by $5-7 \%$. The filterability of centrifuged mud/juice may represent an issue without suspended particles. the physical appearance of the rewarded juice is very splendid with a hint of turbidity containing a limited quantity of coasting bagacillo. A fundamentally the same as greenish hint was additionally detailed by Hionig, while the shading estimation shows a striking improvement because of centrifugation. In Indian conditions, the earth amendment plays a significant factor in the examination of the sugar balance. Rather than the traditional strategy, if the centrifuged juice is legitimately gauged, the sugar balance report could be made progressively precise. This is an extra favorable position of the treatment. 


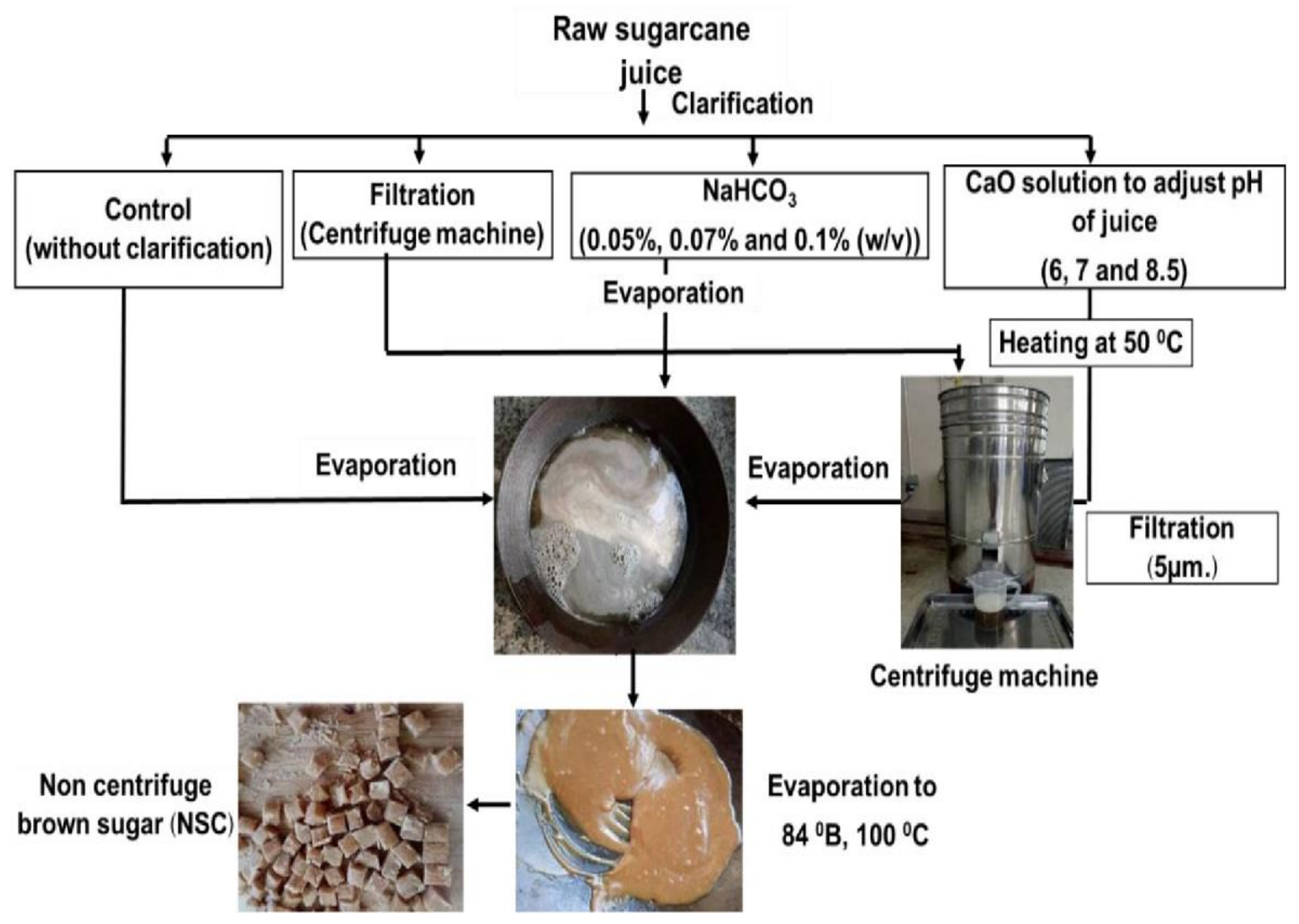

Fig 1: cane juice centrifugation

\section{MATERIALS AND METHODOLOGY}

Cane juice samples were subjected to centrifugation using a Remi R-8 C batch-type laboratory model. This was operated at $6000 \mathrm{rpm}$, attaining $2000 \mathrm{~g}$ at the bottle tip. For every run it was set for 5 minutes. Optimization of the centrifuge operation is a function of design and so was not carried out. Only the various effective parameters due to centrifugation of cane juice have been observed in the present study. Purity measurement of cane juice was done using a Sucromat in a conventional way. A Brookfield RVT viscometer was used to measure the apparent viscosity difference at $50 \mathrm{rpm}$ using spindle No.1 The ICUMSA colour measurement was done using TEA-buffer and membrane filter as described elsewhere. The colour measurements were carried out on an ELICO spectrophotometer. 
III. DATA ANALYSIS AND INTERPRETATION

TABLE I

\begin{tabular}{|l|c|c|c|c|c|}
\hline MEDIUM & $\begin{array}{l}\text { WET } \\
\text { MUD \% }\end{array}$ & $\begin{array}{l}\text { MOIS } \\
\text { TURE }\end{array}$ & $\begin{array}{l}\text { CHEMICAL LOAD } \\
\text { MILK OF LIME }\end{array}$ & $\begin{array}{l}\text { ASH \% ON } \\
\text { CANE }\end{array}$ & $\begin{array}{l}\text { ASH \% } \\
\text { ON }\end{array}$ \\
\hline & W/ & & SO & JUI & MU \\
& W & & 2 & - & - \\
\hline CANE & - & - & $11.8 \mathrm{C}$ & & \\
JUICE & & & C X & 0.1 & 11. \\
\hline TREATED & 5. & 75.7 & $12.5 \mathrm{C}$ & 2 & 5 \\
JUICE & 2 & & C X & & \\
& & & & & \\
\hline
\end{tabular}

TABLE II

\begin{tabular}{|l|l|l|l|}
\hline MEDIUM & $\begin{array}{l}\text { VISCOSITY } \\
\text { CPS }\end{array}$ & $\begin{array}{l}\text { CLARI } \\
\text { TY }\end{array}$ & ICUMSA UNITS \\
\hline CANE JUICE & 1.25 & 42.8 & 4220.00 \\
\hline TREATED JUICE & 1.18 & 13.5 & 3294.00 \\
\hline CLEAR JUICE & 1.02 & 11.8 & 2815.00 \\
\hline
\end{tabular}



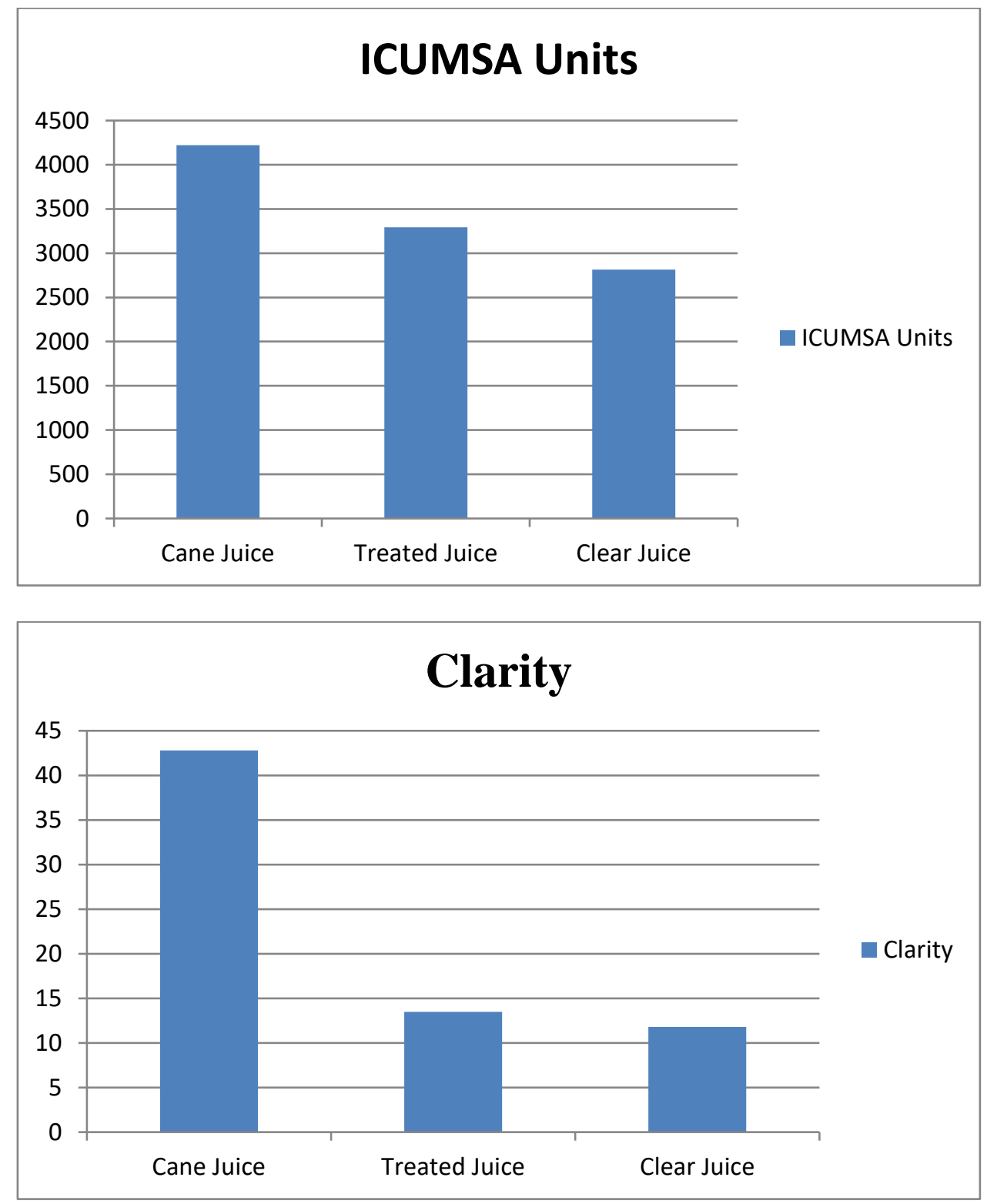

\section{CONCLUSION}

The study involves the centrifugation of cane juice. The juice is subjected to centrifugation directly after milling of the cane. This treatment has been thought of particularly to clarify juices by removing the suspended particles, viz. silica, organic salts, etc. along with mud. In this paper the design pattern of the centrifuge has been shown. The effective factors such as removal of suspended particles, clarity and ICUMSA colour of the centrifuged juice has shown by the table and graph. 


\section{REFERENCES}

[1] Premalatha M (2008) Efficient cogeneration scheme for sugar industry. Journal of Scientific \& Industrial Research 67:239-242

[2] Birru (2007) Investigation of the potential of sugar cane industries (MSc thesis)

[3] Marianela Cordovés Herrera(1999). "CaneSugar and The environment-Cuba conference”. Available at http://www.fao.org/docrep/005/X4988E/x4988e01.htm. Accessed March 2012

[4] Ingaramo A, Heluane $H$, Colombo M, Cesca M (2009) Water and wastewater eco-efficiency indicators for the sugar cane industry.Journal of Cleaner Production $17: 487-495$

[5] Kamate CS and Gangavati BP (2009) Cogeneration in Sugar Industries: Technology Options and Performance Parameters-A Review, Cogeneration \& Distributed Generation Journal, 24:4, 6-33, DOI: $10.1080 / 15453660909595148$

[6] Raghu RJ, Banerjee R(2003)Energy and cogeneration targeting for a sugar factory. Applied Thermal Engineering 23:1567-1575

[7] Ensinas VA, Lozano MA, Serra LM (2007) Analysis of process steam demand reduction and electricity generation in sugar and ethanol production from sugarcane. Energy conversion \& Management 48:2978-2987

[8] Lavarack BP, Hodgson JJ, Broadfoot R, Vigh,S and Venning J (2004) Improving the energy efficiency of sugar factories: Case study for pioneer mill Proc. Aust. Soc. Sugar Cane Technology: 26

[9] ABB (2010) ACS 1000 variable speed drives increase energy efficiency at sugar plant-case study. Available http://www05.abb.com/global/scot/scot216.nsf/veritydisplay/46ae6cf38fa1228bc12577e40056e21d/\$ file/CS_Sugar\%20RevB_lowres.pdf

[10] Dias SOM, Modesto M, Ensinas VA, Nebra AS, Filho MR, Rossell VEC (2011) Improving bioethanol production from sugarcane: evaluation of distillation, thermal integration and cogeneration systems. Energy 36:6, 3691-3703

[11] Solomon S (2011) The Indian Sugar Industry: An Overview. Sugar Technology 13(4):255-265

[12] Keerthipala RA (2007) Sugar Industry of Sri Lanka: Major Issues and Future Directions for Development. Sugar Technology :9(1) 1-10

[13] Ethiopian sugar corporation. Available at http://www.etsugar.gov.et/

[14] Alonso-Pippo W, Luengo AC, Koehlinger J, Garzone P, Cornacchia G (2008) Sugarcane energy useThe Cuban case. Energy Policy 36 : 2163-2181

[15] Edward D (1981)Standard Fabrication Practices for Cane Sugar Mills. Amsterdam: Elsevier Scientific Pub. Co. ; New York: Elsevier Scientific Pub. Co. ; New York: Elsevier Scientific Pub. Co. ISBN0-444-41958-6;ISBN1-322-26407-4;ISBN1-4832-8967-2

[16] Costa, A. F. S.; Nascimento, V. R.; Amorim, J. D. P.; Gomes, E. A. S.; Araujo, L. M.; Sarubbo, L. A. Residue from the production of sugar cane: an alternative nutrient used in biocellulose production by Gluconacetobacter hansenii. Chemical Engineering Transactions, v. 64, p. 7-12, 2018. DOI: 10.3303/CET1864002

[17] Hamerski, F. Study of variables in the process of carbonation of the broth of sugar cane. p. 148. Dissertation. Graduate degree in food technology. Federal University the Paraná, Curitiba, 2009.

[18] Alemu Aderu; 2009; "Energy assessment, energy utilization \& generation efficiency (a case study in Finchaa sugar factory)",MSc thesis 